\title{
Modeling a System of Public - Private Management of Business Areas
}

\author{
Manuel Monterrey, David De La Fuente, Jesús Lozano, Isabel Fernández, and Nazario García
}

\begin{abstract}
Currently, the management structures of the business areas and further industrial sites respond to inefficient models, regardless if is the Public or Private Sector who assumes that management. So far an ideal formula has not been found to ensure the provision of basic and advanced services. Nor is there any national solid reference of Public Private Partnership in the business areas management. Although this already exists in the Real Estate Industry, its analysis is far from the purpose of this paper. Here it is analyzed the model of the British BID (Business Improvement Districts), very successful in revitalizing urban centers and small businesses, and their possible application in the business areas of Spain. This work includes, based on critical analysis carried out on three experiences in England, the definition of a new mixed formula called Concerted Management Model, that relies on the currently existing Spanish legislation and that fully reflects the spirit of the BID system.
\end{abstract}

Index Terms - Industrial park, business area, public-private management, BID( Business Improvement District).

\section{INTRODUCTION}

It is estimated that there were about 4,800 industrial parks in Spain in 2011, in which a large part of the country's economic activity is developed; and since they are territorial spaces of great functional diversity, they have some specific necessities which should be considered if they are to maintain or increase their national richness. Considering the lack of public initiative, a few Spanish private associations have set their own goal: the search of management formulas that are efficient in the resolution of the problems of the industrial areas. In this way, we can find some of the works published by The Spanish Coordinator of Industrial Parks (CEPE) [1] [2]. First, the approach was focused on a normative point of view, formulating proposals of legislative reform in urban matter that could be assumed by the Autonomous Communities or, when appropriate, in a specific regulations about business areas [3]. Until now, only the Principality of Asturias has initiated a normative modification in this matter. In the rest of Communities, the initiative did not flourish, either because it was not addressed or, as in Galicia, because it was not promoted in an effective way. In an additional undertaking, the possibility of finding a suitable management formula was analyzed, but such formula also needed

Manuscript received June 22, 2013; revised August 19, 2013. Financial support given by the Government of the Principality of Asturias is gratefully acknowledged.

The authors are with the Polytechnic School of Engineering (University of Oviedo), Campus de Viesques s/n, CP 33204, Gijón (Asturias), Spain (e-mail: mmonterreym@yahoo.es, david@uniovi.es, lozano@uniovi.es, ifq@uniovi.es,ngarciaf@uniovi.es). normative reforms which were not addressed either. We can say that, if such studies are considered as reference material at a national scale, in practice, the goals have not been reached.

In the General Survey on Business Areas in Spain carried out by CEPE in 2012 on a sample of 250 industrial areas of the 17 Spanish Autonomous Communities, it was detected that $74.9 \%$ of the business areas did not have any kind of organization that grouped together the various interests of the businesses. The formula used in $20.1 \%$ of the cases was that of the Business Association and the other 5\% was organized according to mixed systems, among them Conservation Urban Entity which had a frequency of 3\%. The data have not been substantially altered through the years; nowadays, according to data of CEPE [1] the businesses that are affected by a lack of maintenance of common spaces are at about $55 \%$. In a qualitative way, the opinions of the business owners shown in the survey highlight are as such:

- According to the exclusively public management, the results of the survey establish that it does not reach the minimum levels expected by the businesses regarding to the conservation and provision of basic services.

- Although it counts on numerous defenders in the Public Administration, the management approach through Conservation Entities presents many inconveniences and its basis of mature successful models is insufficient. On the other hand, it implies a double burden (imposing and compensation) [4].

- The expectations for businesses are focused on the management by private specialists or on mixed methods of management, in the line of numerous experiences applied to the urban centers [5]-[9].

Taking into account the limited success registered by the traditional methods of management of business areas in Spain (totally private or totally public), the object of this work is to determine a new model based on the public-private partnership that will be supported by strong points of an unknown methodology in Spain as in the British Business Improvement Districts. Only some aspects of this system will be movable to the Spanish reality, and always after having submitted them to modifications that allow their adaptation and improvement. In this work, we pretend to establish a general model of public-private management inspired in the BID technology that is applicable to any Spanish business area and industrial park, regardless of their geographic location and therefore of the autonomic rules that can be applied. In this sense, it is to be remembered that the totality of the competences in urban matter and productive space management. 


\section{Traditional Management Methods of Business AREAS IN SPAIN}

The various Traditional means of management have been proved inefficient in the compensation of basic services (water, sewer system, etc.) and none of them incorporate directly the management of the businesses based in the area. However, the local entities are obliged to conserve and provide services in business areas in which, due to their small size, lack of business partnership, etc., ii is not possible to find direct collaboration with businesses and it is advisable the employment of an specialised organisation as the Local Development Agencies can be.

Regarding the private management of business sectors, it is to be affirmed that, at the present time, these have been the most successful on the national scene. However, this situation has not been developed naturally, but rather through the replacement of the Administration by Business Associations which assume burdens that legally do not correspond to them; therefore, they cannot be presented as a model to be or as a future method. This is all of the information we have on the advanced point for the matter. As shown, we have not reached a sufficiently satisfactory method, at this point, so it is important to look in detail at methodologies that combine positive aspects of both the public and private management.

The perfect method would incorporate a variety of elements including the following:

- Will agreed by Administration and businesses based on a certain project in which their own financing and actions are detailed for a certain period of time (four or five years).

- $\quad$ Obligatoriety for all business and property owners of the economic contribution or corresponding payment, for the conservation of the urbanization and services traditionally considered as basics, and for all considered essentials, such as the implantation of private security systems or waste residual collection.

- Will agreed by Administration and businesses based on a certain project in which their own financing and actions are detailed for a certain period of time (four or five years).

- $\quad$ To become obligatoriety for all business and property owners of the economic contribution or corresponding payment; To oversee the conservation of the urbanization and services traditionally considered as basics, and for all considered essentials, such as the implantation of private security systems or waste residual collection.

Along the same line, it is here where we find interest for the formula of the Business Improvement Districts (BID); and that although they arise from the of the urban center environment of countries as Canada or United Kingdom, its application is considered viable, with some adaptations, to be applied to Spanish business areas.

\section{Public-Private Partnerships in Business Area MANAGEMENT}

The public-private partnership in industrial areas refers almost exclusively to the financing of the infrastructures in a fixed phase and not to the service management in an operative phase. Expressions such as Public Private Partnership (PPP) and Private Finance Initiative (PFI) have been integrated in the vocabulary of the public sector [10]. The roles played by the public and the private sector in the mixed management of business areas are different, and sometimes even opposed, since there are conflicts of interest and even abandonment of responsibilities. In this way:

- The public sector should provide services according to the needs of the property owners. However, only $51.3 \%$ of the collection services for urban residual waste and water supply are provided by the public sector [1].

- In order to analyse the role of the private sector, it is important to distinguish if they are property owners located in the business area or they belong to other companies. In the first case, there is a common interest in receiving the services in the appropriate conditions of cost, deadline and quality. In the second case, the interest of the property owners is determined by the cash flow generation from the exploitation of the services provided in the business area. Often, the conflicts arise when it is about to select a company located in an industrial park in order to provide a certain service to the rest.

Usually, the public sector looks after the supply of basic services and the private party takes responsibility for the advanced services or added value services, as the energy management, district heating, gardening, maintenance, etc.

\section{A. BIDs (Business Improvement Districts) Methodology}

Business Improvement Districts (BIDs) can be defined as privately directed and publicly authorized organizations that provide additional public services within geographically defined boundaries by generating multiyear revenue from contributions of the property owners or businesses. The Canadian Local Government approved the first BID of the world in December 1969, the Bllor West Village, as a response to an initiative of the local businessmen in order to revitalize the urban center. In the last four decades, more than 700 BIDs have been created in Canada and United States. In Europe, the model came through England a few years after; the first inventoried BID in an urban center is the one located in Kingston in 2004, while the first BID located in an industrial park was put in place in Winsford a year later. In England and Wales the law regarding BIDs dates 2003, while it was approved in 2006 in Scotland. In November 2008, there were 80 BIDs in the United Kingdom; 62 are located in urban centers and the rest in business areas. In United Kingdom, the average size of the BIDs ranges from 300 to 400 property owners; the smallest one has 25 property owners and the biggest one 2500 [11]. The life of the BID is limited to a few number of years (normally five), but it is true that they are rarely dissolved. On the other hand, Bids renew automatically through reauthorization processes provided by law. The model is based on a subdivision of the territory and all businessmen included in it are subject to the mandatory payment of additional taxes for its maintenance, development and promotion [12]-[14]. The tax is called assessment or levy and it is not legally a tax; it is rather a fee or special property tax that the property owners pay in exchange for the services 
they receive. The amount required to be paid by every member of the BID is calculated taking into account factors as the size of the establishment, its facade, fixed value, its use, etc. Special property taxes are collected along with other local taxes by the municipal authorities and, after that, they are transferred to the governing body of the BID for the economic activities or supply of services to benefit the organisation. Regarding the BID management system in the United Kingdom, it is to be highlighted that the great majority are non-profit organizations with own legal entity and they work according their regulation (BID Proposaly Company Articles of Association). Besides, they are usually managed by some of the taxpayers of the established taxes, acting as representatives of the BID [15].

\section{B. Identification of Good Practices in BID Management in Business Areas of the United Kingdom}

As mentioned above, there are few models of the application of the BID methodology in business areas, and the United Kingdom is the only country that has some experience although very limited. In order to understand better the initial phases of the BID methodology and to analyze its possible transfer to the Spanish reality, the author of this work took part in a number of visits and subsequent sessions of benchmarking, together with the persons responsible for three British BIDs during summer 2009. All of them were in an embryonic phase but of no return in the process of the BID activity. In concrete, they were the following:

- Segensworth Estates

- Lancing Business Park

- Southern Cross Industrial Estate

In order to define the activity of such BIDs, the BID Proposal and their main projects were analyzed. Obviously, some of these projects were in full performance, while others have not been initiated yet or have already finished, what provided useful information regarding the degree of compliance in deadline, cost and quality. In order to unify the study, the projects were grouped in six areas for improvement: Transport, Security, Environment, Human Resources, Maintenance and Miscellaneous. Finally, the Key Success Factors of a generic BID in a business area were identified and the conclusion was reached: they were four:

- Interest in the BID creation, measured by the level of participation in the voting process.

- Support to BID, represented by the results obtained in the voting.

- $\quad$ BID budget.

- Services managed by the BID and feasibility of its performance.

The BID with the best punctuation mark is Segensworth Estates, considering that the analyzed BIDs obtain a greater valuation according to the support to the BID creation. The final reflection regarding the benchmarking is that these experiences are still in an initial status of the performance process of the BID taking into account the degree of progress of the projects. This aspect, as a result indicator, it constitutes the main point of interest for the possible adaptation of the methodology to the Spanish business areas. On the other hand, the Key Success Factors detected in the United
Kingdom do not mean a noticeable competitive advantage regarding the degree of progress of the associative formulas that are being applied in Spain. The value of this information resides in the ability of the persons responsible for the Spanish business areas to swiftly apply the aspects of the BIDs that improve their management techniques and which are supported by the current judicial framework, since any normative change (coordinated between the State and the Autonomous Communities) would not be available in the short/medium term. From the analysis it is deduced that the BID system facilitates the possibilities of financing advanced services, but since the costs are finally transfered to the business, it is not considered acceptable to demand them an economic effort in order to take care of this kind of services if the right provision of basic services is not guaranteed; in addition, a double imposition is committed [16], [17]. In this respect, we can maintain that in Spain, it is possible to create a model in which the two main elements identified in the BID formula are incorporated:

- Formalization of an articulated public-private consensus based in a PPP.

- Establishment of a system of mandatory contributions from the property/business owners through the right implementation of the current rules.

\section{IMPLEMENTATION MODEL OF THE BID FORMULA TO THE SPANISH BUSINESS AREAS}

Based on the experiences analyzed in the United Kingdom, we propose the creation of a model of public-private management in business areas which is inspired in the BID system, but that is viable for the Spanish regulatory framework. Such model will be called Co-ordinated Management Model. As a first step, the town council, business and property owners of the business area will create a PPP that will be litigated in a Frame Agreement for the Coordinated Management, in which:

Both parts commit to collaborate and contribute economically to the project financing that has been created on a private management basis.

The financial contribution of the council town has as initial reference the cost of the mandatory basic services. On their behalf, the business and property owners will promise a payment which implies their real joint responsibility in the management formula.

Management would be organized with the principle that each part performs the functions according to their abilities in order to achieve the greatest efficiency of the used resources.

The creation of a BID Project will be started under the protection of the Frame Agreement for the Co-ordinated Management. Courses of action and deadline cost and quality must be clearly specified in the project. It is important that the Project is written by a multidisciplinary technical team with the adequate experience in the management and it should address the following aspects:

- Detection of existing problems.

- Working structure

- Material and human resources.

- Basic services.

- Conservation and maintenance of structures. 
- Advanced services.

- Investment needs.

- Financing Structure.

- Distribution of contribution criteria.

- Campaign design for the project approval.

- Periodification of the action.

The practical BID shows a valuable dynamic in the sense that at the beginning the municipal effort is maximum and it decreases afterwards. Although we can and should turn to accessible grant means, it should be an economic contribution of the country, as a sample of real interest and commitment. Regarding the needed consensus on the private party, we should demand a reinforced majority voting of business and property owners, but counted separately (double majority). A criterion that refers to area or builds ability has to be chosen for the property owners, while for the business owners a criteria based on operative criteria (number of employees, consumption, etc.) must be established. Considering these criteria, the project should be adequately spread and explained, ensuring that the interesting parties understand it. If the Process is successfully overcome, then the Project with the modifications that may be considered pertinent would be submitted to the definitive approval by the town council; if they approve it, the partnership would be created through the Agreement for the Co-ordinated Management of the Business Area, which would have been accepted by both parts. The Agreement would be formalised by the signature of the town council representatives, business and property owners. Based on this Agreement, the management and adoption of the financial predictions will be created in the budgetary area of the signatory town council. Since the private party financing is difficult to achieve voluntarily, the most appropriate mean to obtain it is the constitution of an Urban Entity of Conservation (EUC) which is mandatory for all owners. This EUC will be responsible for the common conservation of the urbanisation and the provision of basic services. The system is not closed, since depending on the approved Project, there would be different levels of cost acceptance and, therefore, of public-private joint responsibility. In any case, what is essential is to maintain the criteria that part of the initial responsibility of the council town is assumed by owners.

On the other hand, the existence of a Business Association is required in order to face the actuations corresponding to the advanced services. Certainly, this entity will not be mandatory and could be organized in different ways; in any case, their rules must respond to the requests expressed in the Project and will be always non-profit entities in which their goods will be affected by the needs of the industrial park which are non-covered by the EUC. On the other hand, the corporate purpose should refer exclusively to the actuations that have to be addressed in the business area, and in concrete, in the Project predictions. As mentioned before, the material areas of the Association should not be coincident with the EUC and could affect:

- Private Security.

- $\quad$ Resource exploitation (parkings, business centers).

- Non-basic service management, etc.

The financing of the Association should come from the contributions of the partners and from a grant of the council town which is already established in the Project, regardless of other contributory grants. Municipal contribution should have a direct correspondence with the costs assumed by the EUC from which the public part is released. On the other hand, the local entity would save a control power of the actuations and of the Project management. Regarding the EUC, control powers are very important because since it is a collaborating and submitted to responsibility entity, their actuations can be recurred before the own municipal entity. As regards the Association, it should be submitted to a control already established in the Project; in this sense, the position of the council town will come determined by its quality of financing entity. However, it is essential to limit the administrative discretion through arbitral formulas that avoid long processes that takes importance away from the system. Regardless of what is mentioned before, it is important that the Project creates an effective system of coordination, both between EUC and the Association, and these ones and the council town. The coordination among the private parties can revolve around the composition of the governing body and the private parts and the council town will rest on a Table of a Business Area equipped by an own performance regime. The result of the creation of a system like the proposed one would have the following result [18].

- Mandatory services would work acceptably.

- All of them would contribute to their financing.

- $\quad$ There would be supplementary services that could result in cost savings of management for the business and in an improvement of the business area.

\section{CONCLUSIONS}

In this work, we have attempted to prove that, being aware that there is no perfect formula for the management of the Spanish business areas, we can transfer experiences of public-private partnership identified in other countries such as the British Business Improvement Districts, solving to a large extent the lack of the traditional methods of totally public or totally private management. It is shown that there is no need to make normative changes, of greater complexity in the Spanish case, due to the transfer of competences of the State to the seventeen Autonomous Communities; and that it is possible to use existing formulas such as the Urban Entity of Conservation or Business Association. In this way, we propose the procedure for the creation, operation, control and improvement of a Outsourcing management structure that will respond to the needs of services of the companies located in the same physical space, regardless of the services are basic or advanced. The results of the benchmarking made with three BIDs located in industrial parks in the United Kingdom shows us that Spain is not far from the most innovative practices which are taking place in other countries, and we cannot make definitive conclusions yet because they have not been tested over the longterm. This circumstance is an opportunity for the country to be situated in first line in the development of compact models of public-private management of productive structures.

What has just been outlined here is hoped to show a possible method towards the promotion of the public-private partnership in the business area management and will favor 
the progress towards the management excellence of the Spanish working mechanism.

\section{REFERENCES}

[1] F. Mora, "Nuevas formas económicas de gestión de las áreas empresariales," in Colección Telemática de las Áreas de Empresariales, Coordinadora Española de Polígonos Empresariales, Oviedo (España), Spanish, no. 1, 2006.

[2] M. Negrete, “Asociacionismo, ¿utopía o realidad?" in Colección Telemática de las Áreas de Empresariales, Coordinadora Española de Polígonos Empresariales, Oviedo (España), Spanish, no. 2, 2008.

[3] F. Mora, "La regulación jurídica de las áreas industriales," Coordinadora Española de Polígonos Empresariales, Oviedo (España), Spanish, 2001.

[4] R. Hale and A. Capaldi, Who Plays for Local Services? The Balance of Fundind between Government and Councils, The Local Government Association Publications, UK, London, 2004.

[5] M. Boddy and M. Parkinson, City Matters: Competitiveness, Cohesion and Urban Governance, The Policy Press, University of Bristol, UK, Bristol, 2004.

[6] C. Cadell and N. Falk, Spreading the Benefits of Town and Centre Renewal, London, UK: LGA Urban Comission, 2005.

[7] J. Egan, The Egan Review: Skills for Sustainable Communities, London, UK: Office of Deputy Prime Minister, 2005.

[8] H. Forsberg, D. Medway, and G. Warnaby, "Town centre management by cooperation: evidence from Sweden," in Cities, London, UK Elsevier, vol. 16, no. 5, 1999, pp. 315-322.

[9] D. Neumark and J. Kolko, "Do enterprise zone create jobs? Evidence from California's enterprise zone program," Journal of Policy Analysis and Management, Cambridge, USA: John Wiley \& Sons, vol. 29, no. 1 , pp. 103-126, 2010.

[10] W. Zonneveld, E. Meijers, and B. Waterhout, "Polycentric development policies in European countries," in Built Enveironment, Oxon, UK: Alexandrine Press, vol. 31, no. 2, 2005, pp. 163-173.

[11] The Association of London Government Local Authority Guide to Business Improvement Districts. (Feb. 9, 2012). [Online]. Available. http://www.ukbids.org/files/files/LA-BIDs.pdf

[12] D. Rudlin and N. Falk, Suistainable Urban Neighborhood, Oxford, UK: Architectural Press, 2006.

[13] J. Sadek, "Regenerations begins at holme," in Estates Gazette, London, UK: The British Urban Regeneration, no. 1036, 2010, pp. 66-68.

[14] A. Simms, Ghost Town Britain, London, UK: New Economics Foundation, 2003.

[15] M. Monterrey and F. Mora, "El sistema BID aplicado a la gestión de áreas empresariales en España,” in Colección Telemática de las Áreas de Empresariales, Coordinadora Española de Polígonos Empresariales, Oviedo (España), Spanish, no. 3, 2010.

[16] L. Hoyt, "Do business improvement district organizations make a difference? Crime in and around commercial areas in Philadelphia," in Philadelphia Journal of Planning Education and Research, London, UK: Sage Publications, no. 25, 2005, pp. 185-194.

[17] R. Melzer, "Understanding business improvement district formation: An analysis of neighborhoods and boundaries," Journal of Urban Economics, Netherlands, Sage Publications, vol. 71, no. 1, 2012, pp. 66-78.

[18] M. Monterrey, "Techo Industrial Protegido," in Promoción de micronaves para autónomos y pymes, Coordinadora Española de Polígonos Empresariales, Oviedo (España), Spanish, 2011.

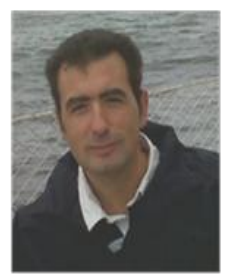

Manuel Monterrey was an I.Mech.E. chartered engineer in UK in 2012. He was a certified senior Project Manager in IPMA level B in 2012, he was also a expert professional engineer IPR-AIPE in 2012. He got the doctor degree from the University of Oviedo in 2006. He has 20 years' experiences as a manager of industrial (CLAS, CAPSA, BUK) and services (Novotec Consultants, Soluziona TYPSA
Consolidates). He is an associate professor at the University of Oviedo since 2002. He is the author of over 35 scientific articles, 4 of them JCR-indexed by Thomson Reuters. He participated as the chairman in 4 international conferences and as a speaker in another 12. His areas of expertise are project management, operations, HR and quality.

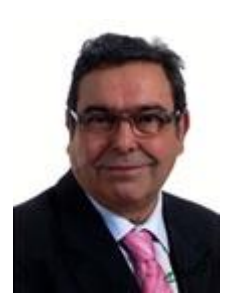

David De La Fuente is a full professor on operations management and management science. He got the Ph.D. on Management Science in 1987 in Universidad de Oviedo (Extr. Thesis Award). He is the vice dean of the Industrial Engineering School, University of Oviedo, Spain from 1987 to1991. He is an invited professor at several Latin-American Universities in Bolivia, Argentina, Cuba, El Salvador etc. He is a member of the International Scientific Committee of 30 Technical Conferences. He is also the director of several research projects (European, national and regional), and contracts with companies. 20 Papers in international journals indexed by JCR and SJR. Member of POMS, EurOMA and INFORMS, etc.

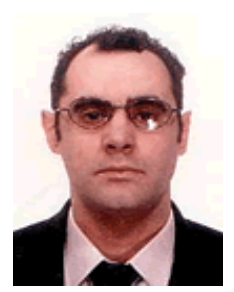

Jesús Lozano was born in Gijón, Spain in1966, he has a degree in Economics and Management by the University of Oviedo, a master in Accountant Audit and a doctorate in Business Administration. Actually he is a professor of Business Administration in the University of Oviedo, Spain.

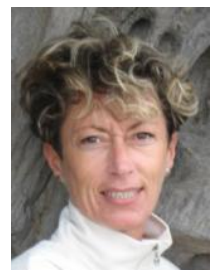

Isabel Fernández is a Ph.D. and MBA. She is a senior lecturer and researcher of the University of Oviedo, Spain since 1997, affiliated to the Business Administration and Accounting Department. In 2002 she enjoyed a 1 year and 9 months permission leave in the University of Vaasa, Finland in the Industrial Management Department. Visiting lecturer of International Management Program in the IESEG in France. Previously she worked in Public sector (1 year), Private sector (2, 5 years) and in a Polytechnic School (1 year). Areas of her interest are logistics (more specifically Reverse Logistics), production organization, costs analysis and forecasting. She is the author of several publications in different national and international journals and chapters of books. She has attended to more than 80 national and international scientific conferences. She Participated in several research projects. She is one of the members of the directors board of the International Society For Productivity And Quality Research.

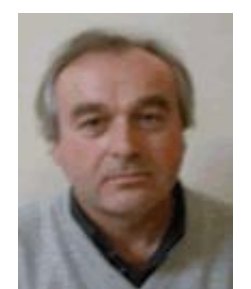

Nazario García is a Ph.D. and MBA. He is a senior lecturer and researcher of the University of Oviedo, Spain since 1998, affiliated to the Business Administration and Accounting Department. He is the former purchasing manager at a military company, where he worked during 24 years. Also he was in charge of supplier evaluation and internal audits. $\mathrm{He}$ is the counselor in rural hotel and industrial waste treatment plant implementation. Several national and international publications. He Participated in six research projects and national and international scientific conferences. Nazario is a visiting lecturer at the University of El Salvador and La Habana, Cuba on Seminars and courses on Marketing, Logistics, Purchasing, Production and Quality. Currently he is the secretary of Austrian Logistics Foundation. 